\title{
PENGEMBANGAN PERANGKAT PEMBELAJARAN MATERI SEGITIGA DAN SEGIEMPAT DENGAN PENDEKATAN RME (REALISTIC MATHEMATICS EDUCATION) UNTUK SISWA KELAS VII MTSN REJOSARI KABUPATEN MADIUN TAHUN PELAJARAN 2012/2013
}

\author{
Maliatul Inayati, Drs. Suroso, M. Pd, Wasilatul Murtafiah,S.Pd,M.Pd \\ FPMIPA IKIP PGRI Madiun
}

\begin{abstract}
Abstrak. Penelitian ini bertujuan untuk mengembangkan perangkat pembelajaran matematika pada materi segitiga dan segiempat dengan pendekatan RME (Realistic Mathematics Education) yang berkualitas baik (memenuhi kriteria kevalidan, kepraktisan, keefektifan).

Pengembangan perangkat pembelajaran menggunakan model pengembangan perangkat pembelajaran 4D yang dimodifikasi menjadi 3-D. untuk mengetahui kriteria kevalidan, keprakisan, dan keefektifan dilakukan pengumpulan data dengan cara penilaian validasi, penilaian observasi, pengisian angket, dan melakukan tes hasil belajar. Setelah itu dilakukan analisis data menggunakan metode statistik deskriptif. Hasil menunjukan, bahwa perangkat pembelajaran dikatakan valid oleh ketiga validator sehingga kriteria dipenuhi. Selain itu kepraktisan perangkat pembelajaran juga memenuhi kriteria penilaian dengan ditunjukannya nilai kemampuan aktivitas guru dalam mengelola pembelajaran di kelas pada ujicoba terbatas 0,99 dan ujicoba lapangan 0,90 . Sedangkan aktifitas siswa dapat ditunjukan dengan nilai pada ujicoba terbatas 3,28 dan ujicoba lapangan 3,30, yang menunjukan kriteria kepraktisan perangkat pembelajaran terpenuhi. Sedangkan untuk kriteria keefektifan perangkat pembelajaran dapat ditunjukan dengan hasil respon positif siswa adalah diatas $80 \%$ seluruhnya pada semua komponen penilaian pada ujicoba terbatas maupun ujicoba lapangan. Untuk tes hasil belajar dapat ditunjukan dengan melihat ketuntasan klasikal siswa pada tahap ujicoba terbatas maupun lapangan secara berturut-turut $100 \%$ dan $76,7 \%$, sehingga kriteria keefektifan juga terpenuhi.

Dari hasil penelitian pengembangan perangkat pembelajaran matematika diatas maka dapat disimpulkan bahwa perangkat pembelajaran mempunyai kualitas baik karena telah memenuhi kriteria kevalidan, kepraktisan dan keefektifan.
\end{abstract}

Kata Kunci: Pengembangan Perangkat, $R M E$, Segitiga dan Segiempat

\section{PENDAHULUAN}

Dewasa ini pendidikan nasional Indonesia sangat penting untuk diperhatikan secara khusus baik pendidikan formal maupun non formal. Ini disebabkan karena peran pendidikan adalah untuk mengembangkan kualitas Sumber Daya Manusia (SDM) di Indonesia yang bertujuan agar menjadi lebih berkualitas dan bermutu tinggi seperti halnya di negara-negara maju di dunia internasional. Pemerintah telah mempercepat perencanaan Millennium Development Goals (MDG), yang semula direncanakan tahun 2020 dipercepat menjadi 2015. Millennium Develoment Goals adalah era pasar bebas atau era globalisasi, sebagai era persaingan mutu atau kualitas, siapa yang berkualitas dialah yang akan maju dan mampu mempertahankan eksistensinya. Oleh karena itu, pembangunan SDM berkualitas merupakan suatu keharusan yang tidak dapat ditawar-tawar lagi, karena akan menjadi penopang utama pembangunan nasional yang mandiri dan berkeadilan serta menjadi jalan keluar bagi bangsa Indonesia dari multidimensi krisis, kemiskinan, dan kesenjangan ekonomi. Agar dapat mewujudkan SDM yang berkualitas tinggi hendaknya dilakukan beberapa inovasi dalam pendidikan di Indonesia agar dunia pendidikan menjadi ruang pengembangan potensi, daya pikir dan daya nalar serta pengembangan kreatifitas yang dimiliki oleh siswa. Pendidikan di Indonesia masih mempunyai banyak masalah yang harus diselesaikan dan salah satu masalah yang harus diselesaikan adalah sistem pemberdayaan guru yang sangat lemah. Pendidikan yang berkualitas adalah dapat melahirkan generasi yang cerdas unggul dan kompetitif di kancah dunia internasional. Karena pada hakikatnya pendidikan adalah proses pematangan kualitas hidup, melalui proses tersebut diharapkan manusia dapat memahami apa arti dan hakikat hidup secara benar. Karena itu fokus pendidikan diarahkan pada pembentukan kepribadian unggul dengan menitikberatkan pada proses pematangan kualitas logika, hati, akhlak, dan keimanan. Puncak pendidikan 
adalah tercapainya titik kesempurnaan kualitas hidup.

Untuk meningkatkan kualitas pendidikan di Indonesia, peranan guru sangat penting sebagai sosok arsitektur yang dapat membentuk jiwa dan watak anak didik. Guru mempunyai kekuasaan untuk membentuk dan membangun kepribadian siswa menjadi seorang yang berguna bagi nusa, bangsa dan agama. Untuk itu guru harus menjadikan pembelajaran berkualitas agar siswa mampu bersaing di kancah internasional. Hal yang lebih khusus yaitu guru diharapkan melakukan pembelajaran yang bermakna, guru adalah sebagai pelaku perubahan agar siswa mampu untuk berubah dari tak tahu menjadi tahu dari tak mengerti menjadi mengerti. Agar pembelajaran berlangsung secara baik dan tidak monoton hendaknya guru harus kreatif dan inovatif dalam memberikan pengalaman belajar yang melibatkan proses mental dan fisik melalui interaksi antara guru dan siswa, siswa dan siswa, siswa dan lingkungan, siswa dan sumber belajar dan lain sebagainya dalam rangka mewujudkan pencapaian tujuan pembelajaran.

Mata pelajaran matematika masih dianggap mata pelajaran yang sulit, abstrak, dan tidak menyenangkan oleh banyak siswa. Hal ini ditunjukan dengan adanya fenomena siswa yang menganggap matematika banyak sekali rumus yang harus dihafalkan. Selain itu guru terlalu monoton dan serius sekali dalam menjelaskan materi matematika sehingga membuat matematika adalah pelajaran paling membosankan. Seorang guru cenderung untuk menjelaskan konsep matematika yang abstrak berdasarkan cara buku. Cara mengajar seorang guru dengan cara buku, merupakan salah satu faktor yang menyebabkan materi matematika itu sulit di pahami oleh siswa. Fungsi seorang guru adalah membantu siswa untuk memahami konsep matematika yang ada di buku paket. Jika pada kenyataanya guru yang bersangkutan menjelaskan konsep yang ada berdasarkan bahasa buku tanpa menggunakan kemampuan mereka untuk membuat penyampaian yang lebih ringan, tentunya hal ini tidak membantu siswa memahami konsep, tetapi membantu siswa membaca buku. Kalau kasusnya sudah seperti ini, tetap saja akan membuat siswa berada pada kebingungan mereka dan pada akhirnya jatuh pada pernyataan bahwa matematika itu sulit. Padahal banyak sekali hal yang bisa dilakukan oleh guru agar pelajaran matematika lebih menarik minat dari siswa. Misalkan saja melalui berbagai pendekatan pembelajaran yaitu pendekatan matematika realistik.

Pendekatan matematika realistik dapat mendorong siswa untuk memahami materi pelajaran secara lebih nyata atau tidak abstrak, karena guru menggunakan contoh atau alat peraga benda yang berada di sekitarnya sehingga mudah dipahami. Hal ini juga dapat merangsang minat belajar siswa akan konsep matematika yang terkesan monoton dan abstrak karena pendekatan matematika realistik sangat erat dengan masalah-masalah yang terjadi pada kehidupan sehari-hari. Sehingga dapat menjadikan pembelajaran matematika lebih nyata atau tidak terkesan abstrak. Dalam hal ini pendekatan matematika realistik membantu sebagian besar siswa memahaami materi yang telah diberikan oleh guru secara menyenangkan dan tidak terkesan abstrak.

Dalam mata pelajaran matematika SMP/MTs (Madrasah Tsanawiyah) khususnya pada materi segitiga dan segiempat pada siswa kelas VII, masih banyak siswa yang mengalami kesulitan belajar, itu dibuktikan dengan hasil belajar siswa yang masih di bawah KKM (Kriteria Ketuntasan Minimum). Banyaknya nilai siswa yang berada di bawah KKM ini disebabkan oleh banyak faktor salah satunya adalah motivasi belajar siswa terlalu rendah. Rendahnya motivasi siswa disebabkan oleh berbagai faktor salah satunya guru yang kurang kreatif dan inovatif dalam pembelajaran di kelas. Hal itu terlihat dari kurang bermaknanya kegiatan pembelajaran yang dilakukan oleh guru, dan sulitnya pengadaan media pembelajaran. Akibatnya, guru biasanya langsung mengajarkan dengan cara buku (teks book oriented).

Agar materi segitiga dan segiempat dapat diterima oleh siswa dengan baik, maka guru dituntut untuk menyampaikan materi dengan kemasan yang menarik dan efektif. Pembelajaran dikatakan menarik dan efektif apabila siswa tertarik untuk memperhatikan dan mengikuti materi yang diberikan dengan baik dan dapat menghasilkan sesuatu yang sesuai dengan apa yang diharapkan atau dengan kata lain tujuan pembelajaran dapat tercapai secara sempurna.

Untuk memenuhi tuntutan akan terlaksananya pembelajaran yang menarik dan efektif. Perlu adanya pengembangan perangkat 
pembelajaran matematika untuk guru, dan siswa, sehingga seorang guru dapat melaksanakan tugas mengajarnya dengan cara yang efektif, dan dapat menarik minat siswa dalam pembelajaran. Pengembangan perangkat ini harus relevan dengan materi yang akan disampaikan oleh guru.

Atas dasar pertimbangan tersebut diatas, maka peneliti termotivasi untuk melakukan penelitian dengan judul "Pengembangan Perangkat Pembelajaran Materi Segitiga dan Segiempat dengan Pendekatan RME (Realistic Mathematics Education) untuk Siswa Kelas VII MTsN Rejosari Kabupaten Madiun Tahun Pelajaran 2012/2013”

\section{PEMBAHASAN}

\section{Landasan Teori}

Paul Suparno (1997:61) belajar berarti membentuk makna. Makna diciptakan oleh siswa dari apa yang mereka lihat, dengar, rasakan, dan alami.

Agus Suprijono (2012:3) belajar dalam idealisme berarti kegiatan psiko-fisik-sosio menuju ke perkembangan pribadi seutuhnya. Namun, realitas yang dipahami oleh sebagian besar masyarakat tidaklah demikian. Belajar dianggapya properti sekolah. Kegiatan belajar selalu dikaitkan dengan tugas-tugas sekolah. Sebagian besar masyarakat menganggap belajar di sekolah adalah usaha penguasaan materi ilmu pengetahuan.

Wina Sanjaya (2008:112) belajar adalah proses mental yang terjadi dalam diri seseorang, sehingga menyebabkan munculnya perubahan perilaku. Aktivitas mental itu terjadi karena adanya interaksi individu dengan lingkungan yang disadari.sedangkan menurut Heri Rahyubi (2012:1) belajar merupakan proses hidup yang sadar atau tidak harus dijalani semua manusia untuk mencapai berbagai macam kompetensi, pengetahuan, ketrampilan, dan sikap. Selain itu beliau juga menyebutkan bahwa belajar adalah merupakan aktivitas menuju kehidupan yang lebih baik.

Muhibbin Syah (1999:59) belajar adalah kegiatan yang berproses dan merupakan unsure yang sangat fundamental dalam menyelenggarakan setiap jenis dan jenjang pendidikan. Sedangkan A Kosasih (2007:47) menyebutkan ada asumsi atau anggapan bahwa belajar adalah semata-mata mengumpulkan atau menghafalkan fakta-fakta yang tersaji dalam bentuk informasi dari materi pembelajaran. Ada pula yang beranggapan bahwa belajar adalah latihan belaka seperti Nampak dalam latihan membaca dan menulis.

Herman Hudojo (1990:1) Belajar merupakan kegiatan bagi setiap orang. Pengetahuan ketrampilan, kebiasaan, kegemaran, dan sikap seseorang terbentuk, termodifikasi, dan berkembang disebabkan belajar. Bila dapat diasumsikan dalam diri orang itu menjadi suatu proses kegiatan yang mengakibatkan suatu perubahan tingkah laku.

Dari beberapa pendapat para ahli diatas dapat disimpulkan bahwa belajar adalah suatu kegiatan yang bermakna yang dilakukan oleh siswa yang memungkinkan siswa membangun sendiri pengetahuannya.

Sukardjono (2007:1.3) menyatakan bahwa matematika adalah cara atau metode berfikir dan nalar. Matematika dapat digunakan untuk membuat keputusan apakah suatu ide itu benar atau salah atau paling tidak ada kemungkinan benar. Matematika adalah suatu medan eksplorasi dan penemuan, di situ setiap hari ide-ide baru ditemukan. Matematika adalah metode berfikir yang digunakan untuk memecahkan semua jenis permasalahan yang terdapat di dalam sains, pemerintahan, dan industri. Matematika adalah bahasa lambang yang dapat dipahami oleh semua bangsa berbudaya. Sedangkan menurut Catur (2009:5) menyatakan matematika adalah ilmu yang tidak jauh dari realitas kehidupan manusia.

Menurut Freundenthal (dalam Tanwey, 2003:51) menyatakan bahwa RME (Realistic Matematics Education) diperkenalkan di Belanda pada tahun 1973. Menurutnya pembelajaran matematika harus dipandang sebagai proses. Materi yang disajikan kepada siswa harus berupa suatu proses, bukan sebagai barang jadi yang siap disuapkan kepada siswa.

Treffers (dalam Tanwey, 2003:51) membedakan empat pendekatan dalam pendidikan matematika yaitu (1) mekanistik (mechanistic), (2) strukturalistik (structuralistic), (3) empiristik (empiristic), (4) realistik (realistic). Sedangkan Menurut Soejadi (dalam Tanwey, 2003:52) RME pada dasarnya adalah pemanfaatan realitas dan lingkungan yang dipahami peserta didik untuk memperlancar proses pembelajaran matematika sehingga dapat mencapai tujuan pendidikan atematika secara lebih baik dari pada masa lalu. 
Menurut De Lange dan HeuvelPanhuizen (dalam Tanwey, 2003:52) RME merupakan pembelajaran matematika yang mengacu pada kontruktivis social dan dikhususkan pada pendidikan matematika. Dalam pandangan $R M E$, pengembangan suatu konsep matematika dimulai oleh siswa secara mandiri berupa kegiatan eksplorasi sehingga memberikan peluang pada siswa untuk berkreasi mengembangkan pemikirannya. Pengembangan konsep berawal dari intuisi siswa dan siswa menggunakan strateginya masing-masing dalam memperoleh suatu konsep. Guru diharapkan tidak tergesa-gesa menyampaikan pemikirannya kepada siswa tentang suatu materi yang sedang dibahas, bila materi yang dibahas agak sukar, siswa dapat membentuk kelompok kecil, sehingga terjadi negoisasi antar siswa dalam mendiskusikan materi yang sulit tersebut.

Salah satu pendekatan dalam pembelajaran matematika yang menekankan penggunaan masalah nyata dalam langkahlangkah membangun pengetahuan adalah pembelajaran matematika realistik (Asrin Lubis, 2006:90). Jadi dapat disimpulkan bahwa RME (Realistics Mathematic Education) adalah pendekatan pembelajaran matematika yang memanfaatkan benda atau lingkungan sebagai bahan untuk alat peraga serta memanfaatkan keadaan kenyataan yang ada di sekitar lingkungan sosial peserta didik sehingga pembelajaran matematika bisa lebih mudah di pahami oleh peserta didik.
Menurut (Dewi Nuharini. 2008:234 dan 251) segitiga adalah bangun datar yang dibatasi oleh tiga buah sisi dan mempunyai tiga buah titik sudut. Sedangkan segiempat adalah enam macam bangun datar segiempat yaitu persegi panjang, persegi, jajargenjang, belah ketupat, layang-layang, trapesium.

\section{Metodologi Penelitian}

Menurut Sudjana (dalam Trianto, 2009:177) untuk melaksanakan pengembangan perangkat pembelajaran diperlukan modelmodel pengembangan yang sesuai dengan sistem pendidikan. Sehubungan dengan itu ada beberapa model pengembangan pembelajaran. Dalam pengembangan perangkat pembelajaran tiga macam model pengembangan perangkat pembelajaran, yaitu: model Dick-Carey, model 4-D dan model Kemp.

Menurut Trianto (2009:177) setiap model pengembangan terdiri dari 4 (empat) tahap:

a. Tahap pendefisian (define), yaitu tahapan yang bertujauan untuk menentukan dan mendefinisikan kebutuhan pembelajaran.

b. Tahap perencanaan (design), yaitu perencanaan prototype perangkat pembelajaran.

c. Tahap pengembangan (develop), yaitu yang bertujuan untuk menghasilkan perangkat pembelajaran.

d. Tahap penyebaran (disseminate), yaitu tahap penggunaan perangkat pembelajaran meliputi langkah-langkah yang secra lengkap ditunjukan pada table 2.2 
Tabel 2.2

Model pengembangan perangkat pembelajaran

\begin{tabular}{|c|c|c|c|}
\hline Tahap & Dick \& Carey & $4-D$ & Kemp \\
\hline $\begin{array}{l}\text { Penetapan } \\
\text { (define) }\end{array}$ & $\begin{array}{l}\text { - Identity instructional goals } \\
\text { - } \quad \text { Conducting a goal analysis } \\
\text { - Identity entry behaviuors \& } \\
\text { characteristic } \\
\text { - Write performance } \\
\text { objectives }\end{array}$ & $\begin{array}{l}\text { - } \quad \text { Support analysis } \\
\text { - } \quad \text { Leaner analysis } \\
\text { - } \quad \text { Task analysis } \\
\text { - } \quad \text { Concept analysis } \\
\text { - Instruction } \\
\\
\text { objective }\end{array}$ & $\begin{array}{ll}\text { - } & \text { Instruction } \\
& \text { problems } \\
\text { - } & \text { Leaner } \\
& \text { charakteristics } \\
\text { - } & \text { Task analysis } \\
\text { - } & \text { Instruction } \\
& \text { objectives } \\
\text { - } & \text { Content sequencing } \\
\text { - } & \text { Instruction } \\
& \text { strategies } \\
\text { - } & \text { Instruction delivery } \\
\end{array}$ \\
\hline $\begin{array}{l}\text { Perencanaan } \\
\text { (design) }\end{array}$ & $\begin{array}{l}\text { Design and conduct } \\
\text { formative evaluation } \\
\text { - Design and conduct } \\
\text { summative evaluation }\end{array}$ & $\begin{array}{ll}\text { - } & \text { Evaluation } \\
& \text { instrumets } \\
\text { - } & \text { Instruction } \\
& \text { resources }\end{array}$ & $\begin{array}{ll}- & \text { Evaluation } \\
& \text { instruments } \\
- & \text { Instruction } \\
& \text { resources } \\
\text { - } & \text { Support services } \\
\end{array}$ \\
\hline $\begin{array}{c}\text { Pengembanga } \\
n(\text { develop })\end{array}$ & $\begin{array}{ll}\text { - } & \text { Develop criterian } \\
& \text { referenced test item } \\
\text { - } & \text { Develop instruction } \\
& \text { strategy } \\
\text { - } & \text { Develop \& select } \\
\text { instructionsl materials }\end{array}$ & $\begin{array}{ll}\text { - } & \text { Instrument } \\
& \text { validation } \\
\text { - } & \text { Tryouts }\end{array}$ & $\begin{array}{l}\text { - Formative } \\
\text { evaluation } \\
\text { - Revision } \\
\text { - Evaluative } \\
\text { evaluation }\end{array}$ \\
\hline $\begin{array}{l}\text { Penyebaran } \\
\text { (disseminate) }\end{array}$ & Instrument implementation & $\begin{array}{c}\text { Instrument } \\
\text { implementation }\end{array}$ & $\begin{array}{c}\text { Instrument } \\
\text { implementation }\end{array}$ \\
\hline
\end{tabular}

Model pengembangan perangkat yang disarankan oleh Thiagarajan, dan Semmel( dalam Trianto, 2009:189) adalah model 4-D. model ini terdiri dari 4 tahap pengembangan, yaitu define, design, develop, dan disseminate, atau diadaptasikan menjadi model 4-P yaitu pendefinisian, perancangan, pengembangan, dan penyebaran.
Rudi Santoso Y (dalam Vigih Hery Kristanto, 2012:108) mengemukakan tiga kriteria untuk menentukan kualitas kurikulum (termasuk perangkat pembelajaran), yaitu validitas, kepraktisan, dan keefektifan. Ketiga hal itu diuraikan sebagai berikut. 
Tabel 2.1 Kriteria kualitas kurikulum

\begin{tabular}{|c|c|c|}
\hline Validitas (validity) & $\begin{array}{l}\text { Kepraktisan } \\
\text { (practicality) }\end{array}$ & $\begin{array}{l}\text { Kefektifan } \\
\text { (effectiveness) }\end{array}$ \\
\hline Yang diharapkan & Konsistensi diantara: & Konsistensi diantara: \\
\hline 1) State-of-the- & $\begin{array}{l}\text { 1) Intended } \leftrightarrow \\
\text { perceived (harapan }\end{array}$ & $\begin{array}{l}\text { 1) Intended } \leftrightarrow \text { ekperiential } \\
\text { (harapan } \leftrightarrow \text { pengalaman) }\end{array}$ \\
\hline $\begin{array}{ll}\text { artof } \\
\text { knowledge } \\
\text { 2) } & \text { Internally } \\
\text { consistent } \\
\text { (Konsistensi } \\
\text { secara } \\
\text { internal) } \\
\end{array}$ & 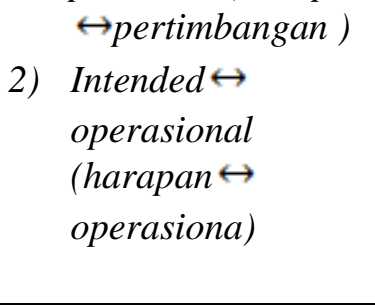 & $\begin{array}{l}\text { 2) Intended } \leftrightarrow \text { attained } \\
\text { (harapan } \leftrightarrow \text { perolehan) }\end{array}$ \\
\hline
\end{tabular}

Kepraktisan perangkat dan keefektifan perangkat pembelajaran didasarkan pada hasil analisis data yang diperoleh dari lapangan (yaitu hasil penerapan perangkat pembelajaran dalam pelaksanaan pembelajaran di kelas) uraiannya adalah sebagai berikut.

Pada penelitian ini, kriteria kualitas material diatas hampir seluruhnya digunakan. Kriteria kualitas material yang tidak digunakan adalah state-of-the-art of knowledge, dan yang digunakan uraian tentang kriteria kualitas material diatas sebagai berikut.

a. Validitas (validity) Model Pembelajaran. Aspek validitas menurut Rudi(dalam Susi, 2008:28), dikaitkan dengan dua hal, yaitu:

1) Apakah kurikulum atau model yang dikembangkan didasarkan pada rasional teoritik yang kuat (validitas isi).

2) Apakah terdapat konsistensi secara internal atau dengan kata lain, apakah semua komponen model pembelajaran yang dikembangkan, secara konsisten saling berkaitan (validitas konstruk).

b. Kepraktisan (practicality) Model Pemebelajaran

Kepraktisan suatu model pembelajaran ditinjau dari hasil penilaian pengamat berdasarkan pengamatannya (intended $\leftrightarrow$ operational) menyatakan bahwa tingkat keterlaksanaan penerapan model dalam pelaksanaan pembelajaran di kelas termasuk pada katergori yang baik. c. Keefektifan (effectiveness) Model Pembelajaran

Dalam pembelajaran ada beberapa pandangan mengenai keefektifan. Rudi (dalam Susi, 2008:28) mengatakan bahwa keefektifan menjawab pertanyaan "Apakah siswa mencapai tujuan pembelajaran yang telah ditentukan untuk setiap satuan pelajaran?". Rudi (dalam Susi, 2008:28) mengemukakan bahwa pembelajaran efektif terjadi bila siswa dilibatkan secara aktif dalam mengorganisasikan dan menemukan hubungan dari informasiinformasi yang diberikan, dan tidak hanya secara pasif menerima pengetahuan dari guru.

\section{Hasil Penelitian}

Kriteria pengembangan perangkat pembelajaran matematika dengan pendekatan RME (Realistic Mathematics Education) memenuhi semua kriteria valid, efektif dan praktis. Sehingga perangkat pembelajaran metematika ini dapat digunakan dalam pembelajran matematika dengan materi segitiga dan segiempat untuk siswa kelas VII SMP/MTs. Kriteria itu dapat dijelaskan dengan tabel sebagai berikut. 


\begin{tabular}{|c|c|c|c|c|}
\hline No & Kriteria & Indikator & Penilaian & Keterangan \\
\hline 1. & Kevalidan & $\begin{array}{l}\text { - Perangkat } \\
\text { Pembelajaran }\end{array}$ & $\begin{array}{l}\text { Semua validator } \\
\text { menyatakan valid }\end{array}$ & Terpenuhi \\
\hline \multirow[t]{2}{*}{2.} & \multirow[t]{2}{*}{ Kepraktisan } & $\begin{array}{l}\text { - Kemampuan aktivitas } \\
\text { guru mengelola } \\
\text { pembelajaran }\end{array}$ & $\begin{array}{c}\text { Semua pengamat } \\
\text { menyatakan cukup } \\
\text { baik }\end{array}$ & Terpenuhi \\
\hline & & - Aktivitas siswa baik & $\begin{array}{l}\text { Semua pengamat } \\
\text { menyatakan cukup } \\
\text { baik }\end{array}$ & Terpenuhi \\
\hline \multirow[t]{2}{*}{3.} & \multirow[t]{2}{*}{ Keefektifan } & - Respon Siswa & $\begin{array}{l}\text { Siswa memberi } \\
\text { respon positif } \geq \\
80 \% \text { dalam setiap } \\
\text { indikator penilaian }\end{array}$ & Terpenuhi \\
\hline & & - Siswa tuntas belajar & $\begin{array}{c}\text { Siswa tuntas } 75 \% \\
\text { secara klasikal }\end{array}$ & Terpenuhi \\
\hline
\end{tabular}

\section{KESIMPULAN DAN SARAN \\ Kesimpulan}

Berdasarkan penelitian pengembangan yang telah dilakukan dapat disimpulkan bahwa:

1. Proses pengembangan perangkat pada penilaian ini dilakukan dengan mengacu pada pengembangan model 4-D karya Thiagarajan yang dimodifikasi menjadi 3D. Kegiatan yang dilakukan dalam pengembangan perangkat pembelajaran tersebut adalah sebagai berikut.

a. Tahap pendefinisian (define)

Tahap ini dimulai dengan melakukan analisis ujung depan, analisis tugas yang didalamnya terdapat analisis materi dan tujuan belajar.

b. Tahap perancangan (design)

Kegiatan pada tahap ini diawali dengan memilih media dan format perangkat pembelajaran sesuai dengan materi luas dan kelilng segitiga dan segiempat dengan pendekatan $R M E$ (Realistic Mathematic Education). Hasilnya digunakan untuk merancang perangkat pembelajaran, yaitu Rencana Pelaksanaan Pembelajaran (RPP), Buku Pegangan Guru (BPG), Buku Siswa (BS), Lembar Kerja Siswa (LKS) dan Tes Hasil Belajar (THB) sebagai Draf awal.

c. Tahap pengembangan (develop)
Hasil Draf awal pada tahap perancangan selanjutnya dikembangkan dengan cara melakukan validasi terhadap Draf awal tersebut kepada ahli validator. Setelah perangkat pembelajaran dinyatakan valid oleh validator, selanjutnya dilakukan uji terbatas kepada siswa. Langkah berikutnya perangkat pembelajaran tersebut diujicobakan pada kelas VIII F MTsN Rejosari.

2. Perangkat pembelajaran matematika dinyatakan valid oleh ketiga Validator.

3. Perangkat pembelajaran matematika dinyatakan praktis berdasarkan pengamatan aktivitas Guru dan Siswa.

4. Perangkat pembelajaran matematika dinyatakan efektif berdasarkan respon positif Siswa dan ketuntasan Tes Hasil Belajar Siswa.

\section{Saran}

Berdasarkan simpulan dari penelitian yang peneliti lakukan di MTs Negeri Rejosari, maka peneliti memberikan beberapa saran sebagai berikut:

1. Bagi Siswa

Peggunaan perangkat pembelajaran matematiak yang telah dikembangkan dengan pendekatan RME (Realistic Mathematics Education) diharapkan siswa lebih aktif di kelas dalam mengikuti proses pembelajaran dan dapat memahami konsep 
yang diajarkan oleh Guru dengan pendekatan kehidupan sehari-hari Siswa. sehingga dapat meningkatkan prestasi belajar matematika siswa.

2. Bagi Guru

Guru matematika diharapkan dapat menerapkan perangkat pembelajaran matematika dengan pendekatan RME (Realistic Mathematics Education). untuk memberikan konsep dengan cara pendekatan sehari-hari Siswa sehingga Siswa lebih mudah menerima konsep yang diberikan oleh Guru.

3. Bagi Sekolah

Hasil penelitian ini hendaknya dapat dipergunakan sebagai masukkan dan pertimbangan bagi Sekolah untuk mengembangkan perangkat pembelajaran matematika yang baru dan inovatif sehingga dapat meningkatkan prestasi belajar matematika Siswa.

4. Bagi Penelitian Mendatang

Jika Peneliti lain ingin melakukan penelitian yang sama tetapi untuk materi yang berbeda, sebaiknnya materi yang dipilih harus materi yang mudah dikaitkan dengan kehidupan sehari-hari Siswa. Sehinnga Peneliti lain tidak kesulitan dalam mengembangkan perangkat pembelajaran yang akan di buat.

\section{DAFTAR PUSTAKA}

Agus Suprijono. 2012. Cooperatif Learning Teori dan Aplikasi Paikem. Yogyakarta: Pustaka Pelajar.

A. Kosasih. 2007. Optimalisasi Media Pembelajaran. Jakarta: Gramedia

Asrin Lubis. Pembelajaran Matematika Realistik untuk Topik Dimensi Tiga di Kelas X SMA Neeri 2 Medan Tahun Pelajaran 2006/2007. Diakses dari (http: jurnal online.isjd.pdii.lipi.go.id) pada tanggal 15 Februari 2013.

Catur Supatmono. 2009. Matematika Asyik.. Jakarta: PT Gramedia Widiasarana.

Dewi Nuharini. 2008. Matematika Konsep dan Aplikasinya. Surakarta: CV Putra Nugraha.

Heri Rahyubi. 2012. Teori-Teori Belajar dan Aplikasi Pembelajaran Motorik Deskriptif dan Tinjauan Kritis. Bandung: Referens.

Herman Hudojo. 1990. Strategi Mengajar Belajar Matematika. Malang:Universitas Negeri Malang.
Intan Puspita. 2012. Efektifitas Pendekatan Realistic Mathematics Education dalam Pembelajaran Matematika Terhadap Hasil Belajar MatematikaPokokBahasan Kubus dan Balok Kelas VIII SMP Negeri 5 Madiun TahunAjaran 2011/2012. Skripsi tidak diterbitkan.Madiun: Progam Studi Pendidikan Matematika IKIP PGRI Madiun.

Muhibbin Syah. 1999. Psikologi Belajar. Jakarta: PT Logos Wacana Ilmu.

Nana Sudjana. 2012. Penelitian dan Penilaian Pendidikan. Bandung: Sinar Baru Algensindo.

Paul Suparno. 1997. Filsafat Kontruktivisme dalam Pendidikan. Yogyakarta: Kanisius Yogyakarta.

Sukardjono .2007. Hakikat dan Sejarah Matematika. Jakarta:Universitas Terbuka.

Susilowati. 2008. Pengembangan Perangkat Pembelajaran Matematika Realistik pada Pokok Bahasan Pengukuran Kelas V Sekolah Dasar. Madiun: Program Studi Pendidikan Matematika Universitas Katolik Widya Mandala Madiun.

Tanwey Gerson Ratumanan.2003. Pembelajaran yang Relevan dengan Kurikulum Berbasis Kompetensi. Surabaya.

Trianto. 2009. Mendesain Model Pembelajaran Inovatif Progresif. Jakarta: Prenada Media.

Wasilatul Murtafiah. 2009. Pengembangan LembarKegiatan Siswa dengan Pembelajaran Matematika Realistik Berbasis Life Skills pada MateriBangun Ruang Sisi Datar di Kelas VIII SMP.Jurnal Pendidikan IKIP PGRI Madiun.

Wina Sanjaya. 2008. Strategi Pembelajaran Berorientasi Standar Proses Pendidikan. Jakarta: Prenada Media.

Vigih Hery Kristanto.Pengembangan Perangkat Pembelajaran Matematika Sekolah Dasar untuk Menumbuhkembangkan Jiwa Kewirausahaan.Jurnal penelitian. Madiun:Universitas Katolik Widya Mandala Madiun.

Zahra Aini. 2009. Mengajar Matematika dengan Pendekatan Realistik. Diakses dari ((http://zahra-abcde.blogspot.com)) pada tanggal 15 Februari 2012 